\title{
РЕФЕРАТЫ.
}

Обзорь акушерско-гинегологической литературы:

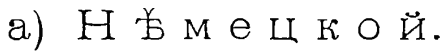

239. 0. А. Рњзниковъ. Zur Kasuistik der „Arthritis gonorrhoica". (Centralbl. f. Gynäk., 1894 г', № 32). Къ казуистикњ перелойнаго воспаленія суставовъ.

У 16 -льтней черезъ 4 дня посль перваго сношенія появилась боль в'ь львомь плечевом' и иравомь локтевомь суставахь. Затьиь сь ознобом'ь и повышенной темшературой появились боли и шрипуханіе праваго кольннаго сустава. IІринуханіе прогрессировало. Бользнь продолжалась 2 мъсяца. Со стороны половыхь органовъ не было измьненій. Мужъ оказался больнымъ острымъ перелоемъ. Авторъ думаеть, что здъсь было зараженіе черезъ ранку разорванной при сношеніи д'ьвственной плевы.

Въ доказательство невърности мн'ънія $I . \quad V$ eit'a, думающаго, что послъ едининало сношенія съ перелойнымь мужчиной, никогда не развивается перелойное воспаленіе тазовой брюшины, яичниковъ и трубъ, авторь приводить 2 случая, гдњ забольваніе придатковъ быстро развилось посль' точно установленнаго единичнаго сношенія съ шерелойнымъ мужчиной.

240. R. Olshausen. Spontane Geburt. Prophylaktische Wendung. Symphyseotomie. Ihr gegenseitiges Verhalten zu einander. (Centralbl. f. Gynäk., 1894 г., № 36). Процзвольные роды.-Профилактическій поворотъ.-Разсьченіе лона.-Ихъ взаимное соотношеніе другъ къ другу.

Авторь не согласень съ Leopold'омъ, ограничившимь показанія къ кесарскому съченію въ пользу симфориеотоміи. По его

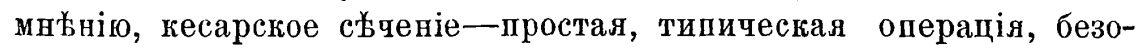


пасная въ рукахъ акушера, вполн'ь усвоившаго законы асептики; симфизеотомія не вполнб безопасна. По поводу выбора между поворотом' и симфизеотоміей шри узкомь тазњ авторъ говорить о возможности въ такихь случаяхт произволныхъ родовъ. ІІри цъломъ пузыр' трудно, говорить онъ, заранъе говорить навърное о томъ, qто произвольные роды будут'ь невозможны. При отошедпихъ водах'ь другое дыло: если размъры головки соотвътственно велики, это становится яснымъ уже qерезъ $1 / 4$ часа посль разрыва пузыря, смотря на силь потужной дьятельности матки. Словомъ. поворотъ, произведенный рано, нисколько не говоритъ, по мнънію автора, в'ь пользу его шреимуществъ сравнительно съ выжидательнымъ способомъ (шроизвольныхъ родовъ). Такое же отношеніе авторь устанавливаеть между симфизеотоміей и произвоьными родами. Вообще-же авторъ большой сторонникъ кесарскаго съченія, и при относительномъ показаніи он'ь дылаеть его

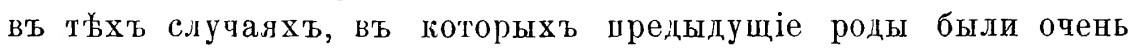
трудны. Въ однихъ случаяхъ, при щъломъ пузыръ, или при наличности потужной цьятельности, авторь дълаеть выборь между выжилательнымъ методомъ, шоворотомъ и кесарскимь съченіемъ, въ другихъ случаяхь, при отсутствіи потужной дыятельности, онъ выбираеть межцу кесарскимъ сьченіемъ и симфизеотоміей.

\section{Н. Какушкинъ.}

\section{Friedrich Schwarz. Sytphyseotomie bei allgemein vereng-} tem Becken mit7,0 cm. Conj. vera. (Centralbl. f. Gynäk., 1894 r., № 36). Разсьченіе лона при обще-съуженномь тазь съ истинной Еонъюгатой въ 7 снтк.

I para, 27 льть; рость 142; размьры таза: cr. 25; sp. 23; c. diagon. 9,0; Baudeloque’овскій размьрь 15; conjug. vera 7 . Отеки тьла; въ мочь бжлюкь. Воды отошли; предлежить головка, глубою, шошеречно. Темшература тьла $38^{\circ}$. Сд влава симфизеотомія на 2 сутки посль начала родовъ; трудно было найти симфизу, уклонившуюся вльво оть средней линіи. Расхожденіе концовъ костей посль্ разсьиченіе лона было 4 снтм., при изв.еченіи щип-

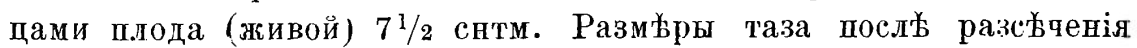
лона были: cr. 30. sp. 27, Bandeloque'овскій размърт 17. ІІосль изв.леченія плода-пвы на мягкія части. жгут Эсмарха на тазъ (с'ь ватной подстилкой), иммобилизація ногъ, катетеръ à demeure. Выздоровленіе черељь 5 недьль, при чемъ размъры таза оказались таковы: cr. 26; sp. 23,5; разм. Bandeloque'a 15,7; conjug. diag. 9; conjug. vera 7. На основаніи 5 случаевъ разсьченія лона 